\author{
ARTIGO \\ do https://doi.org/10.22481/praxisedu.v16i37.6170
}

\title{
THE EFFECTS OF CONVERGENT AND DIVERGENT TASKS ON IRANIAN EFL SPEAKING PERFORMANCE
}

\author{
LOS EFECTOS DE LAS TAREAS CONVERGENTES Y DIVERGENTES EN EL \\ RENDIMIENTO DEL HABLA EFL IRANÍ
}

OS EFEITOS DE TAREFAS CONVERGENTES E DIVERGENTES NO DESEMPENHO DA FALA NO EFL NO IRÃ

Seyed Javad Roudehchi Tabrizi

Islamic Azad University - Iran

Samar Goldouz

Islamic Azad University - Iran

Bahram Hadad Badr

University of Applied Science and Technology - Iran

\begin{abstract}
Resumo: O presente estudo teve como objetivo investigar os efeitos de tarefas convergentes e divergentes no desempenho da fala dos alunos de EFL no Irã. A população inicial deste estudo foi de 100 alunos de EFL. Eles foram selecionados no Mahan language Institute localizado em Karaj, Irã. Todos os participantes eram do sexo feminino. A língua nativa deles era o persa. Após a administração do Teste Preliminar de Inglês (PET), 60 alunos que tiveram seu nível de proficiência intermediário com base nos escores do PET foram selecionados para o estudo. Em seguida, eles foram divididos aleatoriamente em dois grupos experimentais, a saber, grupo de tarefas convergente e grupo de tarefas divergente. Os resultados do estudo revelaram que ambas as abordagens têm diferentes níveis de impacto no desempenho da fala e tarefas convergentes e divergentes afetam diferentemente o desempenho da fala dos alunos intermediários iranianos de EFL. Os resultados demonstraram que a amostra que recebeu tratamento baseado em tarefas divergentes mostrou um desenvolvimento significativo em termos de desempenho na fala (do pré-teste $M=68$ ao pós-teste $M=83$ ).
\end{abstract}

Palavras-chave: Tarefa convergente; Tarefa divergente; Desempenho de fala; Alunos de EFL.

Abstract: The present study aimed at investigating the effects of convergent and divergent tasks on Iranian intermediate EFL learners' speaking performance. The initial population of this study was 100 EFL learners. They were selected from Mahan language Institute located in Karaj, Iran. All of the participants were female. Their native language was Persian. After administering Preliminary English Test (PET), 60 students that their proficiency level were intermediate based on the PET scores were selected for the study. Then they were randomly divided into two experimental groups, namely 
convergent task group and divergent task group. The results of the study revealed that both approaches have different levels of impact on speaking performance and convergent and divergent tasks differently affect Iranian intermediate EFL learners' speaking performance. The findings demonstrated that the sample receiving treatment based on divergent tasks showed a significant development in terms of speaking performance (from pretest $M=68$ to posttest $M=83$ ).

Key words: Convergent task; Divergent task; Speaking performance; EFL learners.

Resumen: El presente estudio tuvo como objetivo investigar los efectos de las tareas convergentes y divergentes en el rendimiento de expresión oral de los estudiantes de EFL intermedios iraníes. La población inicial de este estudio fue de 100 estudiantes de EFL. Fueron seleccionados del Mahan Language Institute ubicado en Karaj, Irán. Todos los participantes eran mujeres. Su lengua materna era el persa. Después de administrar el Examen Preliminar de Inglés (PET), se seleccionaron para el estudio 60 estudiantes que su nivel de competencia era intermedio en base a los puntajes de PET. Luego se dividieron aleatoriamente en dos grupos experimentales, a saber, el grupo de tareas convergente y el grupo de tareas divergente. Los resultados del estudio revelaron que ambos enfoques tienen diferentes niveles de impacto en el rendimiento del habla y las tareas convergentes y divergentes afectan de manera diferente el rendimiento del habla de los estudiantes EFL intermedios iraníes. Los hallazgos demostraron que la muestra que recibió tratamiento basada en tareas divergentes mostró un desarrollo significativo en términos de rendimiento del habla (desde la prueba previa $M=68$ hasta la prueba posterior $M=83$ ).

Palabras clave: Tarea convergente; Tarea divergente; Rendimiento oral; Estudiantes de inglés como lengua extranjera.

\section{Introduction}

Improving speaking skill is of essential importance in EFL/ESL courses. Nunan (1999) and Burkart and Sheppard (2004) noted that success in learning a language is assessed based on the capability to continue a conversation in the (target) language. Thus, speaking is possibly a priority for most students of English (Florez, 1999). Speaking instruction is important because it aids students learn EFL speaking skills thus speak on the spot and naturally with native speakers. In addition, if the proper speaking tasks are taught in the classroom, speaking could address general learners' motivation and the English language classroom will be a fun and dynamic place (Nunan, 1999 \& Celce-Murcia, 2001). Furthermore, speaking could uphold other language skills. Recent studies have regarded oral interaction as a significant factor in the forming of the learner's developing language. For example, it was confirmed that learning speaking could aid the improvement of reading competence (Hilferty, 2005), the development of writing (Trachsel \& Severino, 2004) as well as the improvement of listening skills (Regina, 1997). The terms convergent and divergent have derived from Kolb's (1984) experiential learning theory who has stated that learning is the process whereby knowledge is created 
through the transformation of four distinct modes of experience: concrete experience (CE), active experimentation (AE), reflective observation (RO), and abstract conceptualization (AC). Some people are analytic and others can assimilate facts into theories. These learning differences led Kolb to classify learning styles into four separate learning styles which influence the range of choices in decisions a learner makes. In convergent learning style, learners do best in situations where there is only one solution to a problem. On the other hand, divergent learning style learners perform better in situations where there could be more than one answer. Divergent learners can view concrete situations from many angles; therefore, the task where this kind of learning is encouraged may lead the learners to achieve better learning outcomes (Kolb, 1984). According to Kolb (1984), divergent tasks allow independent works which individuals can perform differently according to their cognitive styles and they might lead to different outcomes. According to Ellis (2003), in divergent tasks learners have independent goals to accomplish. This is true about the debates in which each group is given an opposite role on a controversial issue that they must defend. Therefore, the present aims at answering the question of whether convergent/divergent tasks instruction has any significant effect on the Iranian EFL learners' speaking skill.

The overarching question of the present study was as follows,

Do convergent and divergent tasks differently affect Iranian intermediate EFL learners' speaking performance?

\section{Review of the Related Literature}

\section{Task Based Language Teaching (TBLT)}

Generally, TBLT is considered as an approach to language teaching which attempts to produce native- like accuracy within a communicative classroom, in which task is the unit of analysis. In addition, task-based language is an approach to language teaching that provides opportunities for students to engage in the authentic use of the target language through task. As the principal component in TBLT, the task provides the main context and focus for learning, and it encourages language use similar to the way language is used outside of the classroom. Students learn language and develop skills as they work toward completing task, which motivates them stretch their available language resources (Ellis, 2003).

In recent years a number of researchers, syllabus designers and educational innovators have called for a move in language teaching toward task-based approaches to instruction 
(Prabhu, 1987; Nunan, 1989, \& Ellis, 2003). Since the advent of communicative language teaching and the belief that language is best learned when it is being used to communicate messages, the communicative task has ascended to a position of prominence as a unit of organization in syllabus design. Nunan (2004), for example, proposed a task-based unitary framework because it "leads to student-led holistic outcomes in the form of written reports, spoken presentations and substantial small-group conversations that lead to decision-making outcomes" (p. 70). This interest in the task has been motivated to a considerable extent by the fact that 'task' is seen as a construct of equal importance to second language acquisition (SLA) researchers and to language teachers (Pica, 1997). The rise of task-based language teaching has led to a variety of different interpretations of what exactly constitutes a task. Central to the notion of a communicative task is the exchange of meanings. Willis (1996) defined task as an activity where the target language is used by the learner for a communicative purpose (goal) in order to achieve an outcome. Here the notion of meaning is subsumed in 'outcome'. Likewise, for Nunan (2006) tasks have a non-linguistic outcome. He defines task as a piece of classroom work that involves learners in comprehending, producing or interacting in the target language while their attention is focused on mobilizing their grammatical knowledge in order to express meaning, and in which the intention is to convey meaning rather than to manipulate form. The task should also have a sense of completeness, being able to stand alone as a communicative act in its own right with a beginning, middle and an end (Nunan, 2006).

\section{Convergent/Divergent Task}

Convergent tasks focus on recognizing the familiar results, reapplying techniques, and accumulating information. Divergent thinking, howsoever, causes the learner to make and evaluate much more creative ideas and draw unexpected connections (Nezhat \& Shorkhpour, 2013). Furthermore, convergent tasks are known as those tasks "that require true justified knowledge, abstract conceptualization, and active experimentation. They allow for collaboration in meaning negotiation of where a single goal is needed; thus, collaborative work is required" (Skehan, 2001). These tasks should elicit "only one correct answer, allow collaborative work with short answers of which are not highly cognitively demanding, and so require no reference making" (Astika, 2004, p.30). Convergent tasks require all participants to get the same goal as a regarded result; with divergent tasks, the goals are expected to be varied. The two task types activate various cognitive strategies. Thus, the results of the two task types 
can be varied when cognitive styles are implemented by learners (Nezhat \& Shorkhpour, 2013). Despite convergent tasks, divergent tasks are those that demand new significant information and have different outcome options with likely several goals (Marashi \& Sizari, 2015). In similar lines, Swan (2005) stated that "these types of tasks allow independent works which individuals can perform differently according to their cognitive styles and which might lead to different outcomes" (p. 382). Questioning in divergent tasks enables students to pose questions with more than one correct answer. In such a context, there is no correct answer or answers as the possible responses rely on one's viewpoint or experience (Nielsen et al., 2008). Duff (1986) states that in convergent condition tasks, pairs of learners are asked to solve a given problem together to agree on a justifiable solution to it. While in divergent condition tasks, pairs of learners are asked to cover a broad range of topics and operations and they are assigned different viewpoints on an issue, and they are asked to defend the given position and refute their partner's with as many arguments as possible. Duff further elaborates the finding of his study stating that convergent tasks (e.g. problem solving) produce more negotiation of meaning than divergent ones (e.g. debating). He concludes that convergent tasks result in more comprehensible input than divergent tasks but that the latter lead to more output. In addition, divergent tasks produce more words and greater utterance complexity than convergent tasks. Nunan (1989) also reports the finding of his study: convergent problem-solving tasks prompted significant interactional and discourse differences with more and shorter turns than divergent debating tasks. In another study, Long (1989) reports that convergent tasks result in more turns, questions, and confirmation checks per task than divergent task.

\section{Speaking Skill}

Of the four language skills (listening, speaking, reading and writing), speaking seems intuitively the most important. People who know a language are referred to as 'speakers of that language, as if speaking included all other types of skills, and many, if not most foreign language learners are primarily interested in learning to speak (Ur, 2006). Speaking is an interactive process of constructing meaning that involves producing, receiving and processing information (Brown, 1994; Burns \& Joyce, 1997). Its form and meaning are dependent on the context in which it occurs, including the participants themselves, their collective experiences, the physical environment, and the purposes for speaking. Speaking requires that learners not only know how to produce specific points of language such as grammar, pronunciation, or 
vocabulary (linguistic competence), but also they understand when, why and in what ways to produce language (sociolinguistic competence) (Cunningham, 1999). Swain (1985), an important contributor of immersion- based evidence, was led to consider whether other factors beside input might affect language competence. In particular she proposed the "comprehensible output hypothesis", that is, to learn to speak we have actually to speak. Swain argued that knowing that one will need to speak makes one more likely to attend to syntax when one is listening. Levelt (1989) identified three autonomous processing stages in speech production: (1) conceptualizing the message, (2) formulating the language representation, and (3) articulating the message. Wilson (1997) claimed that children who can translate their thoughts and ideas into words are more likely to succeed in school. Students who do not develop good listening and speaking skill will have life-long consequences because of their deficit. He also pointed out that speaking skills do not need to be taught as a separate subject. These skills can easily be integrated into other subject matter. This is because, students learn talking, clarify thoughts by talking, comprehend better with discussion of reading, write better after talking during writing conferences, develop confidence by speaking in front of peers, and provide a window to their own thinking through their talk.

\section{Bottom-up and Top-down Approaches}

Reviewing related literature to defining speaking showed that two main approaches were implemented to define speaking, the bottom-up and the top down approach. Regarding the bottom up view, Bygate (1987) noted that traditionally the focus in speaking was on motor perceptive skills. It is regarded as mixing sounds in a systematic approach, based on language specific rules to make meaningful statements. Audio-lingual method adopted this approach. At last, with regard to teaching speaking, the bottom-up approach recommends that teaching should be started with the smallest units- sounds-and moved via learning words and sentences to discourse (Cornbleet \& Carter, 2001). In fact, the problem with this approach is that it ignores the social dimension of speaking, restricting it only to its psychomotor mode. Furthermore, it is demanding to insure a satisfactory generalization from supposed learning in the classroom to real life implementation of the skill. Alternatively, Bygate (1998) supports adopting a definition of speaking on the basis of interactional skills which includes making decision about communication. This is regarded a top- down perspective of speaking. Adopting this view, Howarth (2001) considered speaking as a two-way process including a true communication of 
ideas, information or affections. This top-down perspective regards the spoken texts the product of interaction between two or more interlocutors in shared physical context. Therefore, proponents of this view recommend that learners should be encouraged to participate in spoken discourse from the beginning and later they will learn the smaller units (Nunan, 1989). Elaborating more on the interactive essence of speaking, Luoma (2004) described speaking as an interactive process of creating meaning that consists of producing, receiving and processing information. The form and meaning of speaking rely on the situation in which it takes place, including the subjects themselves, the physical context, and the aims of communication. It is often spontaneous, open-ended, and evolving. Speaking in L2 has occupied a peculiar position throughout much of the history of language teaching, and only in the last two decades has it begun to emerge as a branch of teaching, learning and testing in its own right, rarely focusing on the production of spoken discourse (Bygate, 2002). Graham- Marr (2004) mentioned many reasons for focusing on listening and speaking when teaching English as a foreign language, not least of which is the fact that we as humans have been learning languages through our ears and mouth for thousands upon thousands of years, far longer we as humans have been able to read. Although not a set curriculum in most schools, speaking skills have been found to be a fundamental skill necessary for a child success in life.

\section{Empirical Studies}

Marashi and Sizari (2015) investigated the comparative impact of convergent and divergent task on EFL learner's writing and motivation. The results demonstrated that the learners in the convergent group benefited significantly more than those in the divergent group in terms of improving their writing but the two treatments were not significantly different in terms of improving the learners' motivation. Nezhad and Shokrpour (2013) explored the influence of the cognitive style, convergent/divergent thinking, on reading comprehension performance through convergent versus divergent task types. The results showed that the best results were attained when divergent thinkers of the divergent task type group answer referential, and multiple-response items while the worst results were achieved when convergent thinkers in the convergent task group's performance on multiple-response items was implemented as the criterion for reading assessment. Nurdiana (2017) investigated whether convergent and divergent tasks result in different students' speaking performance in term of complexity, accuracy and fluency which task between convergent and divergent is 
able to optimize learners' autonomy. The result showed that there was no a significance difference between convergent and divergent tasks on students speaking performance in term of complexity. And the findings showed convergent group outperformed on the posttest of students' speaking accuracy than the divergent group. Regarding fluency, the findings reveled that there was no significance difference between convergent and divergent tasks on students' speaking fluency. And also it was found that divergent task is better in optimizing students' autonomy.

\section{Method}

\section{Design of the Study}

This study follows a quasi-experimental method, with a pre-test, post-test design. The researcher estimated the effects of independent variables (convergent and divergent tasks) on a dependent variable (speaking performance).

\section{Participants}

The participants of this study were selected based on availibility and language proficiency. The initial population of this study was $100 \mathrm{EFL}$ learners. They were selected from Mahan language Institute located in Karaj, Iran. All of the participants were female and they were between 15 to 19 years old. Their native language was Persian. After administering Preliminary English Test (PET), 60 students that their proficiency level were intermediate based on the PET scores were selected for the study. Then they were randomly divided into two experimental groups in which convergent task group is used for the first experimental group and divergent task for the second experimental group.

\section{Instrumentation}

\section{Preliminary English Test}

The reading and writing sections of PET (last version) was administered for homogenizing the participants at the beginning of the study. PET is the intermediate level Cambridge TESOL exam, which is appropriate for those who deal with everyday written and spoken communications (e.g. read simple books and articles. write a simple personal letter, 
make notes during a meeting). It covers four main language skills (reading. writing, listening and speaking) using material from real life situation. Reading section has 5 parts and 35 reading comprehension questions while the writing section consists of three parts and 7 questions. The candidates are expected to comprehend the main points from journals, signs, newspapers and be able to use vocabulary and structures correctly in 1 hour and 30 minutes. In the listening section, which lasts 30 minutes, the learners are required to follow and understand a range of spoken materials including announcements and discussion about everyday life, and, finally, in the speaking section, which includes 4 parts lasting 10-12 minutes, learners took part in conversation, ask and answer questions and talk freely.

\section{Pretest and Posttest}

PET speaking module was regarded as the pretest of the study. And it was used as a posttest to measure the participants' speaking performance after treatment sessions and the learners were asked to choose a topic and speak about it, so their fluency, accuracy and use of correct words and phrases were assessed.

\section{Convergent and Divergent Tasks}

The convergent and divergent tasks of the study were chosen from American English File series. The validity of the tasks was proved by two experts in the field. 10 convergent tasks and 10 divergent tasks were implemented in the present study.

\section{Data Collection and Data Analysis Procedures}

After administrating PET, 60 learners were selected based on the results of the test. Next, they were randomly divided into two experimental groups. They participated in a pretest and answered the related questions. The pretest speaking scores were kept for further comparison and analysis with the posttest. The treatment sessions were held in 10 sessions. Every session lasted 70 minutes. Experimental divergent group received instruction through divergent tasks, and experimental convergent group received instruction through convergent tasks. Both groups received the same amount of instruction. In the divergent task group, tasks were designed in such a way that students were directed to produce alternative ideas. When 
doing the divergent tasks, the participants were asked to pose opposite ideas, so to raise controversial discussions. They were also asked to express as many opinions as possible, negotiate with others, and defend their positions. In the convergent task group, tasks encouraged participants to collaborate in order to reach a single best answer. In other words, participants were required to reach an agreement collectively.

For analyzing the data, descriptive and inferential statistics were used. The obtained pre and post-test scores were transferred into SPSS, which is statistical software. As for the descriptive statistics, median, maximum, and minimum scores were tabulated. To see if the hypothesis was to be tested through a parametric test or a non-parametric one, for each pair of data, first, the Kolmogorov-Smirnov test was implemented to check the normality of the scores. Based on the outcomes of the normality tests, the research hypothesis was tested utilizing the statistical procedure of paired-samples t-test.

\section{Results}

\section{PET Results}

PET was administered to 100 participants to determine their English language proficiency level. The descriptive statistics, as shown in Table 4.2, reflects that the mean, median and mode of PET scores are 54.66, 54, and 60 respectively. These central parameters are not very far from each other denoting that the scores are dispersed around the mean normally.

Table 1 - Descriptive Statistics for PET

\begin{tabular}{lllllll}
\hline$N$ & Mean & Median & Mode & $S D$ & Skewness & Kurtosis \\
\hline 100 & 54.66 & 54.00 & 60 & 9.396 & .273 & -.651 \\
\hline
\end{tabular}

Based on the results of PET, those 60 students whose scores were one standard deviation (9.39) plus and minus the mean (54.66) (scores between 45 and 64) were selected. Also Table 1 shows that the PET scores are normally distributed as the ratios of skewness and kurtosis over their respective standard errors do not exceed the ranges of $+/-1.96$. 


\section{Checking the Normality of the Data}

Before testing the hypotheses, the participants' pretest scores were checked in terms of normality of distribution. Therefore, the Kolmogorov-Smirnov test was run. According to Pallant (2011), if the result of the Kolmogorov-Smirnov would be insignificant, the distribution is normal and thus a parametric test (paired-samples t-test) could be run. Otherwise, the alternative non-parametric test is optimal.

Table 2 - The Kolmogorov-Smirnov Test of Normality on the Data Sets

\begin{tabular}{cccc}
\hline & Statistic & Df & Sig. \\
\cline { 2 - 4 } Pretest Divergent & .098 & 60 & $.200^{*}$ \\
Pretest Divergent & .089 & 60 & $.200^{*}$ \\
Posttest Convergent & .100 & 60 & $.200^{*}$ \\
Posttest Convergent & .083 & 60 & $.200^{*}$ \\
\hline
\end{tabular}

*. This is a lower bound of the true significance.

As shown in Table 2, the values of the Kolmogorov-Smirnov test were insignificant. Therefore, the normality condition was met. Consequently, paired-samples t-test was used to compare the participants' scores before and after the treatment.

\section{Investigating the Research Question}

According to Table 3, the sample receiving treatment based on convergent tasks showed a partial development in terms of speaking performance (from pretest $M=70$ to posttest $\mathrm{M}=72$ ). This shows that convergent tasks did not have a significant impact on speaking performance and may be some other factors have led to this partial change in speaking performance of the sample under the study.

Table 3 - Descriptive Statistics

Std. Std. Error

\begin{tabular}{llrrrr} 
& & Mean & N & Deviation & \multicolumn{1}{c}{ Mean } \\
\hline Pair 1 & Convergent Task Group Pretest & 70.7143 & 30 & 4.86412 & .65068 \\
\cline { 2 - 5 } & Convergent Task Group Reading Posttest & 72.5179 & 30 & 4.19658 & .57192 \\
\hline \multirow{2}{*}{ Pair 2 } & Divergent Task Group Pretest & 68.5357 & 30 & 4.02224 & .53524 \\
\cline { 2 - 5 } & Divergent Task Group Posttest & 83.8750 & 30 & 8.64401 & 1.15652 \\
\hline
\end{tabular}


Based on table 3, the sample receiving treatment based on divergent tasks showed a significant development in terms of speaking performance (from pretest $M=68$ to posttest $M=83$ ). This shows that divergent tasks had a significant effect on speaking performance.

Table 4 - Paired Samples Test

\begin{tabular}{|c|c|c|c|c|c|c|c|c|c|}
\hline \multicolumn{10}{|c|}{ Paired Samples t-test } \\
\hline & & \multicolumn{5}{|c|}{ Paired Differences } & \multirow[b]{4}{*}{$\mathrm{t}$} & \multirow{3}{*}{\multicolumn{2}{|c|}{$\begin{array}{l}\text { Sig. } \\
(2- \\
\text { tailed }\end{array}$}} \\
\hline & & \multirow[b]{3}{*}{ Mean } & \multirow{3}{*}{$\begin{array}{c}\text { Std. } \\
\text { Deviation }\end{array}$} & \multirow{2}{*}{\multicolumn{3}{|c|}{$\begin{array}{l}95 \% \text { Confidence } \\
\text { Interval of the } \\
\text { Difference }\end{array}$}} & & & \\
\hline & & & & & & & & & \\
\hline & & & & Mean & Lower & Upper & & df & ) \\
\hline Pair 1 & $\begin{array}{l}\text { Convergent Task Group Pretest - } \\
\text { Convergent Task Group Posttest }\end{array}$ & -.80345 & 2.09325 & .27853 & -1.3754 & -.24485 & -2.886 & 30 & .037 \\
\hline Pair 2 & $\begin{array}{l}\text { Divergent Task Group Pretest- } \\
\text { Divergent Task Group Posttest }\end{array}$ & -13.3486 & 8.50875 & $\begin{array}{r}1.1354 \\
2\end{array}$ & -15.6264 & -11.0735 & -11.78 & 30 & .000 \\
\hline
\end{tabular}

The results of table 4 in response to the research question asking whether divergent tasks have any significant effect on Iranian intermediate EFL learners' speaking performance or not shows the significance threshold was set at .0 that is $\mathrm{p}<.0$. This result can be interpreted as unlikely to be due to chance. Therefore, the present study found strong evidence on the relationship between divergent tasks and their effects on Iranian intermediate EFL learners' speaking performance.

The results of table 4 shows the significance threshold was set at .037 that is $p<.037$. The evidence might be considered strong but the present study does not confirm a strong impact because of the obtained results that only confirms a partial impact of convergent tasks on Iranian intermediate EFL learners' speaking performance. The results of the study in response to the research question showed that divergent tasks and convergent tasks differently affect Iranian intermediate EFL learners' speaking performance.

\section{Discussion and Conclusion}

The results of the study revealed that both approaches have different levels of impact on speaking performance and convergent and divergent tasks differently affect Iranian intermediate EFL learners' speaking performance. The findings demonstrated that the sample receiving treatment based on divergent tasks showed a significant development in terms of speaking performance (from pretest $M=68$ to posttest $M=83$ ). This showed that divergent tasks had a significant effect on speaking performance. Recently, many research studies have been undertaken which indicate that TBLT generally implies a more positive effect on learning (e.g. 
Latchem, Latchem, \& Jung, 2010; Makumar, 2010; Marashi \& Hatam, 2009; Plews \& Zhao 2010; Pourdana, Karimi Behbahani, \& Safdari, 2011). Consequently, the researcher engaged in the design and process of the present study with the above paradigm in mind that TBLT does create remarkably positive findings. Both of convergent and divergent tasks present the learners the chance to improve their speaking performance. It is essential for engaging single-goal cooperation and multiple-result collaborative acquisition, between emphasizing stated knowledge and requiring novel significant knowledge, and between cognitively simple and difficult test items. Convergent tasks group could produce a good command of input; however, this group could not produce more output. They could learn better by saying examples and tapping on their background knowledge for reaching a single solution than brainstorming and they tried to create various solutions for a problem. They are required to collaborate with other learners toward a single result that did not provide the students opportunity to create more ideas. Therefore, it was probable for them to get better accuracy. Both convergent and divergent tasks provide the learners a relax context that allowed them to reduce stress or fear and speak and discuss with other classmates. Thus, it was the opportunity for them to speak fluently. In addition, the learners of both groups were encouraged to perform the real and meaningful tasks while they provided the chance to actively take part in fulfilling the tasks.

Divergent tasks motivated the learners to produce different results with probably more than one aim. Furthermore, through asking question in divergent tasks group the learners can pose questions with more than one possible true answer that did not require collaborative work. Additionally task types allowed independent works which individuals could do differently based on their cognitive styles that increased the possibility of producing more outcomes. The findings of the present study are in line with Nurdiana (2017) who found that divergent tasks were better in optimizing students' autonomy in their speaking performance. But the findings are not in harmony with Marashi and Sizari (2015) who investigated that the learners in the convergent group benefited significantly more than those in the divergent group in terms of improving their writing.

The findings of the study can have a number of pedagogical implications. Iranian EFL teachers can help the learners to improve their accuracy and fluency of speech by designing and using effective tasks. To achieve a more systematic impact, course designers can include such tasks as part of the syllabus in all speaking courses. Teachers and curriculum designers need to devise different types of tasks and provide opportunities for EFL learners to be engaged in doing different tasks in the classroom. One of the major implications of the 
findings of this study is the significance of including divergent tasks in different parts of the instruction process. As reported above, divergent tasks have a positive impact on learners' language production. Such a similar positive effect seems to provide EFL teachers with a higher level of confidence in implementing divergent tasks in their speaking classes. As this study is only about the difference between convergent and divergent tasks on speaking performance, more research should be carried out to investigate convergent and divergent tasks on different language skills such as listening in order to investigate which task is more effective.

\section{REFERENCES}

Astika, G. (2004). A task-based approach to reading English for specialist purposes. EA Journal, 22(2), 22-35.

Brown, H. D. (1994). Principles of Language Learning and Teaching. San Francisco: Prentice Hall Regents.

Burkart, G. \& Sheppard, K. (2004). Content ESL across the USA: A Training Packet. A Descriptive Study of Content-ESL Practices. National Clearinghouse for English Language Acquisition.

Burns, A. \& Joyce, H. (1997). Focus on Speaking. Sydney: National Center for English Language Teaching and Research.

Bygate, M. (1987). Speaking. Oxford: Oxford University Press.

Bygate, M. (1998). "Theoretical Perspectives on Speaking”. Annual Review of Applied Linguistics.18 (1), 20-42.

Bygate, M. (2002). Effects of task repetition on the structure and control of oral language. In M. Bygate et al.., (Eds.), Researching pedagogic tasks: Second language learning, teaching, and testing (pp. 23-48). Harlow: Longman.

Celce-Murcia, M. (2001). "Language Teaching Approaches: an Overview". In M. CelceMurcia (Ed.), Teaching English as a Second or Foreign Language (3rd Ed.). Boston: Heinle \& Heinle.

Cornbleet, S. and Carter, R. (2001). The Language of Speech and Writing. London:

Routledge.

Cunningham, F. M. (1999). English language learners' speaking skill. Eric Digest. Retrieved January, 15, 2009, from, ttp//:www.Eric.ed .gov

Duff, P. A. (1986). Another look at interlanguage talk: Taking task to task. In R. R. Day (Ed.), Talking to learn: Conversation in second language acquisition, (pp. 147-181).

Rowley, MA: Newbery House.

Ellis, R. (2003). Task-based language learning and teaching. Oxford: Oxford University Press.

Florez, M. A. (1999). "Improving Adult English Language Learners' Speaking Skills". ERIC Digest. (ERIC Document Reproduction Service No. ED: 435204

Graham-Marr, A. (2004). Teaching skills for listening and speaking. Retrieved, April, 9, 2009, from, http://www Abax . Co. jp/downloads/ extension/ETJ 2004.

Hilferty, A. (2005). "The Relationship between Reading and Speaking Skills". Focus on Basics. http://www.ncsall.net/?id=328, accessed on 22nd May, 2006. 
Kolb, D.A. (1984). Experiential learning: Experiential learning and development. Newjersy: Practice-Hall,Inc.

Latchem, C., Latchem, C. R., \& Jung, I. (2010). Distance and blended learning in Asia. New York: Taylor \& Francis.

Levlet, W. J. M. (1989). Speaking: from Intention to Articulation. Cambridge, Mass: MIT Press.

Long, M. (1989). Focus on form: A design feature in language teaching methodology. In K. de Bot, R. Ginsberg \& C. Kramsch (Eds.), Foreign language research in cross-cultural perspective (pp. 39-52). Amsterdam: John Benjamins.

Luoma, S. 2004. Assessing Speaking. Cambridge: Cambridge University Press.

Makumar, R. (2010). The impact of different task variance on writing proficiency. Retrieved on October 6, 2011, from: www.scripties.let.eldoc.ub.rug.nl/root/Master/ DoorstroomMasters/ToegepasteTaalwetens/2010/Makmur.

Marashi, H., \& Hatam, G. (2009). Using tasks in a content-based program: Does it enhance vocabulary learning? Iranian Journal of Teaching English as a Foreign Language and Literature, 1(4), 73-91.

Marashi, H., \& Shizari, T. Parisa. (2015). Using Convergent and Divergent Tasks to Improve Writing and Language Learning Motivation. Iranian Journal of Language Teaching Research, 3 (1), 99-117.

Nezhad. R., \& Shokrpour, G. N. (2013). The Impact of Task Type and Divergent Thinking on Reading Proficiency. International Journal of English Language and Literature Studies. 2 (2), 124-137.

Nielsen, H., Bayard, M., Pickett, C., \& Simonton, D. (2008). Conceptual versus experimental creativity: Which works best on convergent and divergent thinking tasks? Psychology of Aesthetics, Creativity, and the Arts, 2(3), 131-138.

Nunan, D. (1989). Designing Tasks for the Communicative Classroom. New York: Cambridge University Press.

Nunan, D. (1999). Second Language Teaching and Learning. Boston: Heinle \& Heinle Publishers.

Nunan, D. (2004). An Introduction to Task Based Teaching. Cambridge: Cambridge University Press.

Nunan, D. (2006). Task-based language teaching in the Asia context: Defining 'task'. Asian EFL Journal, 8(3), 12-18.

Pica, T. (1997). Second language teaching and research relationships: A North American view. Language Teaching Research, 1, 48-72.

Plews, J. L., \& Zhao, K. (2010). Tinkering with tasks knows no bounds: ESL teachers' adaptations of task-based language-teaching. TESL Canada Journal, 28(1), 41-59.

Pourdana, N., Karimi Behbahani, M., \& Safdari, M. (2011). The impact of task types on aspects of Iranian EFL learners' writing performance: Accuracy, fluency, and complexity. IPEDR, 20, 261-265.

Prabhu, N.S. (1987). Second Language Pedagogy. Oxford: Oxford University.

Regina, S. (1997). English Language Arts: A Curriculum Guide for the Middle Level (Grades 6-9). Canada: Saskatchewan Education.

Skehan, P. (2001). “A Non-marginal Role for Tasks”. ELT Journal, 56(3), 289-295.

Swain, M. (1985). Communicative competence: some roles of comprehensible input and comprehensible output and its development. In S. Gass, C. Maden (Eds.). Input in Second Language Acquisition. Roleway, Mass: Newbury House. 
Swain, M. (1985). Communicative competence: some roles of comprehensible input and comprehensible output and its development. In S. Gass, C. Maden (Eds.). Input in Second Language Acquisition. Roleway, Mass: Newbury House.

Swan, M. (2005). Legislation by hypothesis: The case of task-based in-struction. Applied Linguistics, 26(3), 376-401.

Trachsel, M. \&Severino, C. (2004). The Challenges of Integrating and Balancing Speaking and Writing in First-Year Rhetoric Classes.

Ur, P. (2006). A Course in Language Teaching: Practice and theory $\left(13^{\text {th }}\right.$ Ed.). Cambridge: Cambridge University Press.

Willis, J. (1996). A Framework for Task-Based Learning. Harlow: Longman.

Wilson, J. A. (1997). A program to develop the listening and speaking skills of children in a first grade classroom. In C. Smith, (Ed). Skills students use when speaking and listening. Retrieved November, 15,2008, from http://eric.indiana.edu

\section{SOBRE OS AURORES:}

\section{Seyed Javad Roudehchi Tabrizi}

Department of English Language Education, Marand Branch, Islamic Azad University, Marand, Iran. E-mail: javad_tabrizi@hotmail.com

(iD) http://orcid.org/0000-0001-6593-4478

\section{Samar Goldouz}

Department of English Language Education, Marand Branch, Islamic Azad University, Marand, Iran. E-mail: goldouz.samar62@gmail.com

(iD http://orcid.org/0000-0002-6207-2443

\section{Bahram Hadad Badr}

Department of Power Plant Mechanics, Azerbaijan University of Applied Science \& Technology, Tabriz, Iran. E-mail: bahram_hadadbadr68@yahoo.com

(iD) http://orcid.org/0000-0002-3359-0735

Recebido em: 28 de outubro de 2019 Aprovado em: 19 de novembro de 2019

Publicado em: 20 de janeiro de 2020 